\title{
遠心圧縮機による配管内圧力脈動に関する研究*
}

（第 3 報，配管系に接続されたドラム内の圧力脈動に関する検討）

\author{
林慈 朗*1, 金子成 彦*2

\section{Pressure Pulsations in Piping Systems Excited by a Centrifugal Compressor (3rd Report, The Characteristics of the Pressure Pulsations in the Drum Connected to the Piping System)}

Itsuro HAYASHI ${ }^{* 3}$ and Shigehiko KANEKO

\author{
${ }^{* 3}$ Chiyoda Advanced Solutions Corporation,
1-1-25 Shin-Urashima-cho, Kanagawa-ku, Yokohama-shi, Kanagawa, 221-0031 Japan
}

\begin{abstract}
The characteristics of the pressure pulsations in the drum connected to the piping system excited by centrifugal compressors or blowers at blade-passing frequency were investigated. In this study, the equivalent resistance of a compressor and that of piping systems were introduced to the three dimensional calculation model, so that the non-linear damping proportional to velocity squared in the system is properly incorporated. As a result, the pressure response in the drum as well as pipe can be well evaluated by this model. Furthermore, the effect of the acoustic dynamic absorber on the pressure pulsations in the pipe and drum is evaluated. It is shown that the maximum pressure amplitude in the drum is obtained when the resonant frequency in the pipe is slightly shifted from the resonant frequency in the drum under the small damping conditions. The effect of the damping in the drum and the mode shape in the drum on the maximum pressure amplitude in the drum is discussed.
\end{abstract}

Key Words: Pressure Pulsation, Centrifugal Compressor, Centrifugal Fan, Blade Passing Frequency, Acoustic Dynamic Absorber

\section{1. 粕 言}

配管内に設置された遠心圧縮機や遠心送風機はイン ペラの回転に伴い羽根通過周波数成分 (Zn 成分) の圧力 脈動を生じ, 配管の振動や高騒音の発生要因となるこ とがある. したがって, 設計段階で配管内の脈動応答 を評価する必要があることから，これまで管路内の伝 播特性に着目した検討が行われてきた ${ }^{(1)} \sim^{(3)}$. 著者ら ${ }^{(2)}$ （4) は遠心圧縮機を含む配管系システム全体の減衰を 等価抵抗係数としてモデル化することで, 配管内の脈 動応答を 1 次元波動モデル(5) 〜(7)により評価する手法を 構築した. その結果, 平均流量 0 を含む幅広い運転点 において，オリフィスによる脈動低減効果も含めて配 管内の脈動応答が 1 次元波動モデルにより評価できる

\footnotetext{
* 原稿受付 2008 年 4 月 28 日.

*1 正員, 千代田アドバンスト・ソリューションズ(株) (釆221 0031 横浜市神奈川区新浦島町 1-1-25).

*2 正員, フェロー, 東京大学大学院工学系研究科 (丞 113-8656 東京都文京区本郷 7-3-1).

E-mail : itsuro.hayashi@ chas.chiyoda.co.jp
}

ことを示した. 一方, 配管系システムにドラムやタン クなどの大口径容器が接続されている場合には, 脈動 の周波数が高くなると容器内で 3 次元の音響共振が生 じることがあり ${ }^{(8)(9)}$, 脈動に起因した高周波振動によっ て構造物が破損し得ることも報告されている(8)．その ため, 容器内脈動応答に関しては 3 次元の脈動分布を 評価する必要がある.

本研究では, 配管にドラムが接続された系において, 遠心圧縮機によって生じる圧力脈動に対するドラム内 の脈動応答を評価するために, これまでに構築してき た 1 次元の配管内圧力脈動の評価モデル(2) (4) 3 次元 に拡張した。本モデルでは配管内流速に依存した速度 二乗形の非線形减衰を, 圧縮機励振部の集中抵抗とし て扱うことにより，配管内脈動応答の算出においては， 無减衰で計算を行うことが可能となるため, 汎用の音 響解析コードが適用できる. 構筑した 3 次元モデルを 用いた検討結果から, 配管内と容器内の共振周波数が 近接した場合に発生する音響動吸振効果に関しても, 本モデルにより良好に評価できることを示した. また， 容器内の堿衰や容器内のモード形状が系全体の脈動応 答に与える影響に関して検討を行った。 


\section{2. 主な記号}

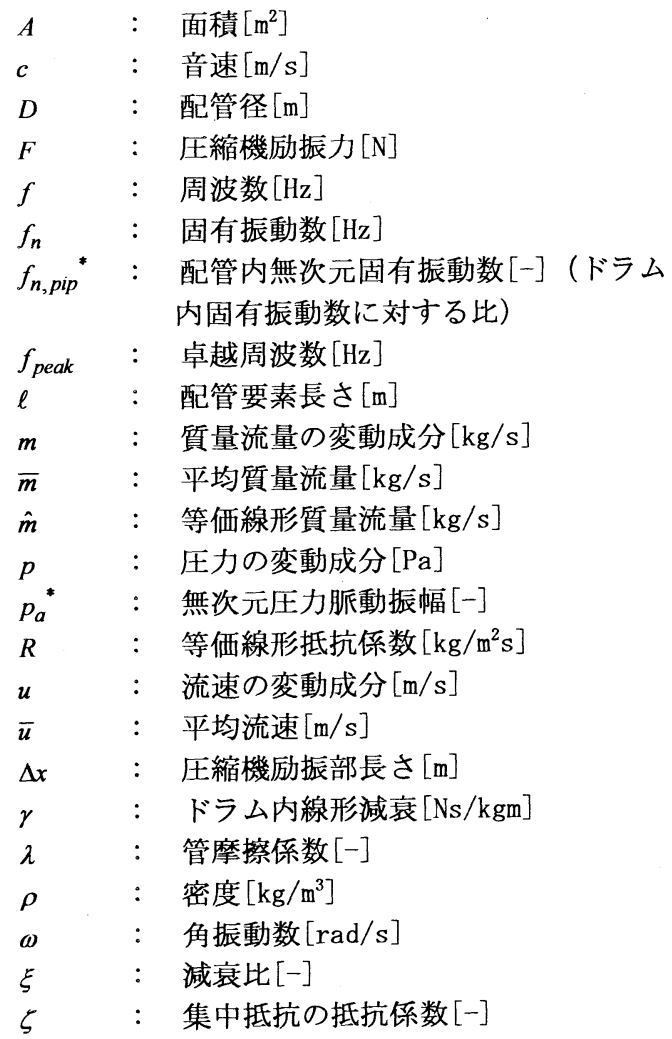

添字

$\begin{array}{lll}c & : & \text { 圧縮機励振部 } \\ d & : & \text { 圧縮機励振部吐出側 } \\ d r u m & : & \text { ドラム内 } \\ \text { in } & : & \text { 配管入口 } \\ \text { out } & : & \text { 配管出口 } \\ p & : & \text { 配管要素 } \\ p i p & : & \text { 配管全体 } \\ r & : & \text { 配管系集中抵抗 } \\ s & : & \text { 圧縮機励振部吸入側 } \\ t & : & \text { システム全体 }\end{array}$

\section{3. 眍管内脈動の計算手法}

$3-1$ 計算モデル 本研究では, 配管系に接続さ れたドラム内の 3 次元脈動応答を評価するため, 図 1 に示すとおり，圧縮機を含む配管系の 3 次元モデルを 構築した. また, 脈動計算において沉用の音響解析ソ フトの適用を可能にするため, 配管系のモデルを压縮 機舌部付近の断面（以下圧縮機励振部とする）で吸入 側モデルと吐出側モデルに分割し（図2），両モデルの
境界に対して，後述する圧力境界条件を与えた.この ようにモデルを分割することで，音響解析ソフトに特 殊な機能を付加することなく, 圧縮機励振部における 励振力および配管系全体に亘る速度二乗形の非線形减 衰を扱うことが可能となる，なお，脈動応答計算には 汎用音響解析ソフト SYSNOISE を用い, 計算手法として 有限要素法を適用した. 計算手法の詳細に関して以下 に述べる.

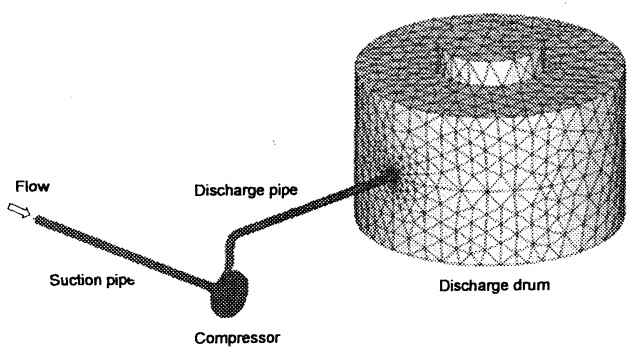

Fig.1 Three dimensional simulation model for finite element method.

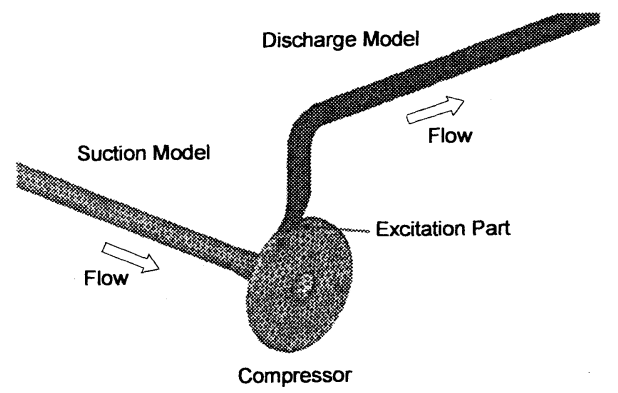

Fig.2 Connection part of the suction and discharge model

3-2 䐆動堛振モデル 圧縮機励振部で発生す る圧力脈動は，既報 ${ }^{(2) \sim(4)}$ 同様， 1 次元で取り扱え るものとし，式(1)により，圧縮機励振部の流体に 外力として与えた。 また, 配管内の減衰に関して は, 非線形减衰を扱うことができない汎用音響解 析コードを用いて, 脈動応答計算を行うために, 既報 ${ }^{(2) ~(4)}$ 同樣に圧縮機励振部に対して式(1)〜式 （4）を適用し，ドラムを除く配管系システムと圧縮 機内部の減衰を表す等価抵抗係数 $\zeta_{l}$ を導入した. 式(4)に示す等価抵抗係数を用いることで, 配管内 流速に依存した速度二乗形の非線形减衰を, 圧縮 機励振部の集中抵抗として扱うことができるため, 脈動応答算出時には配管各要素毎の減衰の計算が 不要となる。すなわち配管内では無減衰で脈動応 
答を算出すれば良いため, 汎用音響解析コードが 適用可能となる. なお, 式(1)〜式(4)において, $x$ は配管の軸方向とし, $u, m$ は配管の軸方向成分とし た.

$$
\begin{aligned}
\frac{\partial m_{d}}{\partial t} & +\bar{u} \frac{\partial m_{d}}{\partial x}+A_{c} \frac{p_{d}-p_{s}}{\Delta x}+\frac{R_{t}}{\Delta x} u_{d}=\frac{F}{\Delta x} \\
m_{d}= & m_{s}-\frac{\partial p_{d}}{\partial t} \cdot \frac{A_{c} \Delta x}{c^{2}} \\
R_{t}= & \frac{\zeta_{t}}{2} \hat{m} \\
\zeta_{t}= & \zeta_{c}+\zeta_{\text {rin }} \frac{\left(\rho_{c} A_{c}\right)^{2}}{\left(\rho_{\text {rin }} A_{\text {rin }}\right)^{2}} \frac{\bar{m}_{\text {rin }} m_{\text {rain }}{ }^{2}}{\bar{m}_{c} m_{c a}^{2}} \\
& +\zeta_{\text {rout }} \frac{\left(\rho_{c} A_{c}\right)^{2}}{\left(\rho_{\text {rout }} A_{\text {rout }}\right)^{2}} \frac{\bar{m}_{\text {rout }} m_{\text {raout }}{ }^{2}}{\bar{m}_{c} m_{c a}^{2}} \\
& +\sum_{i=1}^{N} \lambda \frac{\Delta \ell_{i}}{D_{i}} \frac{\left(\rho_{c} A_{c}\right)^{2}}{\left(\rho_{p} A_{p}\right)^{2}} \frac{\bar{m}_{p i} m_{\text {pai }}{ }^{2}}{\bar{m}_{c} m_{c a}{ }^{2}}
\end{aligned}
$$

3 -3 ドラム内洁衰 本研究で吐出側配管に 接続したドラムは，配管に対して十分容積が大き いことから，ドラム内平均流速に起因した圧力損 失による减衰は小さいと考えられる.したがって, ドラム内の減衰は気体の粘性, 熱伝導, 分子の回 転緩和現象等に起因した音響堿衰が支配的になる と考えられることから, 式(5)に示すようにドラム 内各要素において変動速度に比例した線形减衰 $\gamma$ を与えることで, ドラム内の減衰を評価した，な お, 線形减衰 $\gamma$ の算出手法については, $5 ・ 3$ 節に 示す.

$$
\rho \frac{\partial \mathbf{u}}{\partial t}+\nabla \mathbf{p}+\gamma \rho \mathbf{u}=0
$$

\section{3-4 計算手而図 3 に本手法による脈動計} 算手順を示す。最初に吸入側・吐出側両モデルの 圧縮機励振部に対して適当な圧力境界条件を与え, 無减衰での配管内速度分布を算出する. 次に, 式 (2)を満たすように圧縮機励振部の変動質量流量 を変化させる.なお, 式(2)右辺第二項は第一項に 対して十分小さいため, 簡単のため $m_{d}=m_{s}$ とした. 次に算出した配管内速度分布を用いて，等価線形 質量流量および等価抵抗係数を式(4)より算出す る. 続いて圧縮機励振部において励振力に対する 式(1)左辺各項の大きさを求め, 励振力と釣り合う （式（1）を満たす）ように変動質量流量 $m_{\phi}, m_{s}$ を変
化させる. 最後に収束した変動質量流量条件から 配管全体の脈動応答を求める，なお，無减衰での 配管内速度分布算出においては，線形計算である ため, 初期の圧力境界条件に対する速度分布形状 を一度だけ計算しておけば良く，圧縮機励振部の 変動質量流量の変更毎に再計算する必要はない.

したがって, SYSNOISE を用いた応答計算は一度だ けであり, 収束計算は等価線形質量流量の算出時 にのみ実施することから，計算負荷を大幅に低减 できる、また，ドラム内の脈動応答計算は以下に 示す 2 通りの手法で算出した.

(1)分離型モデル : 配管とドラムのモデルを分離 し, 配管・ドラム接続部を開口端の境界条件とし て, 配管内の脈動応答を算出した後に, 配管・ド ラム接続部の変動速度をドラムへの入力条件とし てドラム内脈動応答を算出する.

(2)一体型モデル：図 1 に示す通り吐出配管にド ラムが接続された配管・ドラム一体型モデルを用 いて, 配管と同時にドラム内の脈動応答を算出す る.

なお，分離型モデルを用いた計算では，配管モ デルを 1 次元で作成することが可能であり, 計算 負荷を低减できることから, 容器を含む配管系シ ステム内の脈動応答計算 ${ }^{(8)(9)}$ に用いられているも のの, ドラム内応答が配管内応答に与える影響は 考慮されていない. 本研究では, ドラム内の脈動 応答が系全体の脈動応答に与える影響を把握する ために, (1)(2)の両手法に関する比較検討を行った.

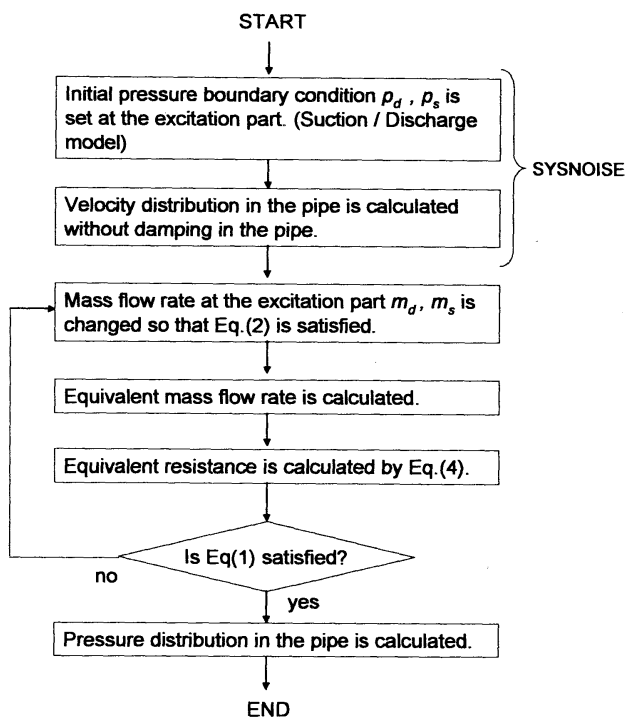

Fig.3 Calculation flow 


\section{4. 実験装置および方法}

本研究では図 4 に示す実験装置を用いて，配管 内圧力脈動ならびにドラム内圧力脈動を計測した. 実験に用いた遠心圧縮機および配管は既報 ${ }^{(2)(3)}$ と 同じ機器であり, 内径 $31 \mathrm{~mm}$ の吐出配管に径 $1.0 \mathrm{~m}$, 高さ $0.6 \mathrm{~m}$ のドラムが設置されている. ドラム内の 音響減衰を算出する際には, 配管系を取り外し, ドラムノズルから打撃音を投入することで, 対象 モードでの自由振動波形を計測した。

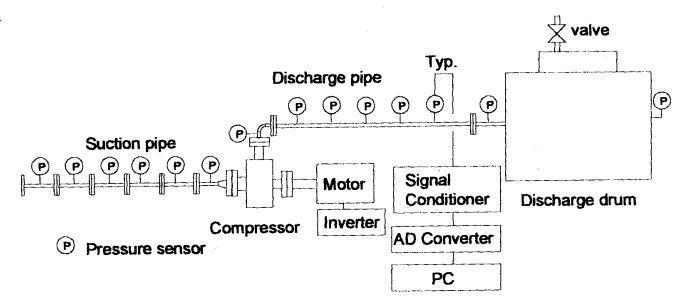

Fig.4 Experimental setup

内と配管内の共振周波数が一致したときに最も脈動応 答が大きくなっており, 実験結果と傾向が異なる。一 方, 図 9 に示す一体型モデルによる配管内脈動応答算 出結果では, 配管とドラムの分離型モデルでは評価で きない配管内三次モードとドラム内径方向モードの共 振周波数一致に伴う脈動応答の低減 (音響動吸振効果) が良好に評価できることが明らかとなった。この現象 は, ドラム内共振によってドラム接続部における圧力 振幅と速度振幅の比（以下インピーダンスとする）が 変化することに対応している. 図10に一体型モデルに おいて算出した配管・ドラム接続部におけるインピー ダンスを示す. 図 10 より, ドラム内の径方向モードの 共振周波数近傍では，インピーダンスが急激に大きく なるため,ドラム接続部を開口端とした配管内のモー ドが存在しなくなり, 図 9 に示すように配管内の脈動 応答が低減すると考えられる.

なお，ドラム内脈動応答に関しては，図 11 に示すよ うに分離型モデルでは, 実験結果の 10 倍以上の脈動応 答が算出された.一方, 図 12 に示す一体型モデルでは, ドラム内脈動応答に関しても良好に評価できることが 明らかとなった。

\section{5. 結果および考察}

5-1 正管内䚽動度答 図 5 および図 6 に本計算 モデル（分離型モデルおよび一体型モデル）によって 算出した吐出配管内脈動の周波数応答と実験結果を併 せて示す. 圧力脈動振幅は, 遠心圧縮機羽根車外周速 度を用いた動圧により無次元化した. 圧縮機励振力, 抵抗係数などの圧縮機励振部諸量に関しては, 既報(2)(3) 同様に実験的に算出した。すなわち，配管端部よりス ピーカで音響加振を行い, 压縮機前後の圧力脈動を計 測することにより，圧縮機の伝達マトリックスを算出 した上で, 運動方程式に基づき圧縮機励振力および圧 縮機内の抵抗俰数を算出した. 図 5 , 図 6 より, 分離型 モデルおよび一体型モデルの両手法において，圧縮機 励振部に等価抵抗係数を適用することで, 配管内脈動 忘答が良好に評価できることが示された。なお，配管 内 3 次モード (206Hz) においては, ドラム内で図 7 に 示す径方向の音響共振（色の濃さが圧力変動の大きさ を表す）が発生することから，配管内脈動応答がドラ 厶内脈動応答の影響を受ける. 図 8 に示すドラム内共 振周波数付近の配管内脈動応答計測結果では, ドラム 内と配管内の共振周波数が一致したときに配管内の脈 動応答が低減することがわかる. しかしながら, 分離 型モデルによる配管内脈動応答算出結果では, ドラム

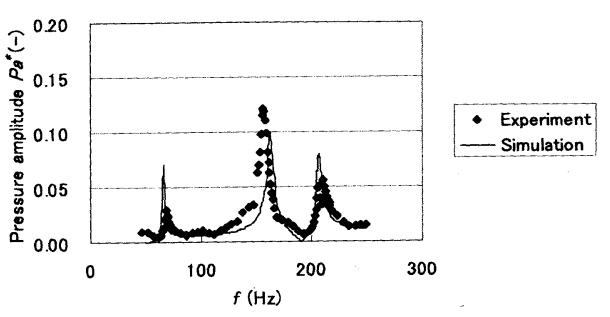

Fig.5 The frequency response of pressure pulsations in the discharge pipe. Separated model is applied.

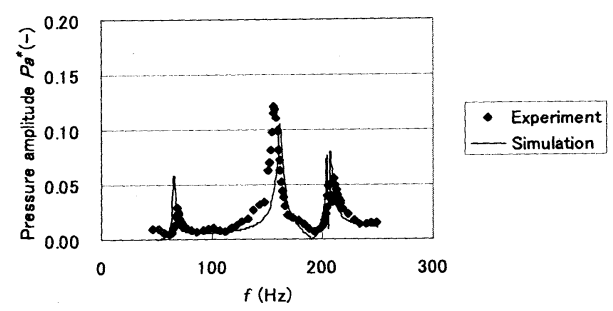

Fig.6 The frequency response of pressure pulsations in the discharge pipe. Integrated model is applied. 


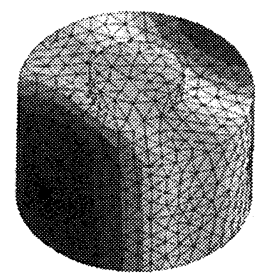

Fig.7 Pressure response of the diametral resonant mode in the drum at $206 \mathrm{~Hz}$.

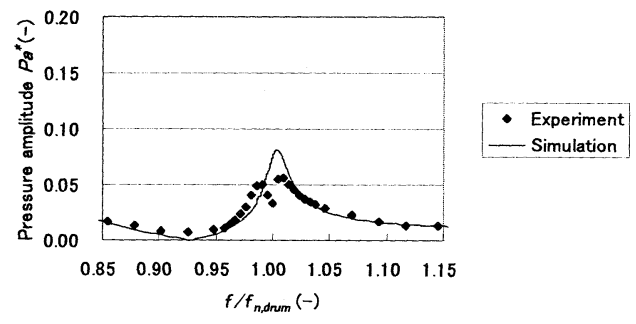

Fig.8 The frequency response of pressure pulsations in the discharge pipe around the resonant frequency in the drum. Separated model is applied.

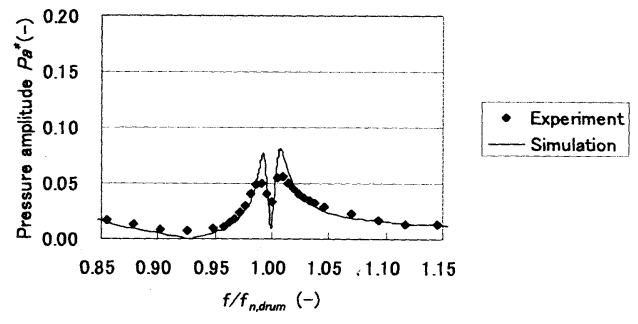

Fig.9 The frequency response of pressure pulsations in the discharge pipe around the resonant frequency in the drum. Integrated model is applied.

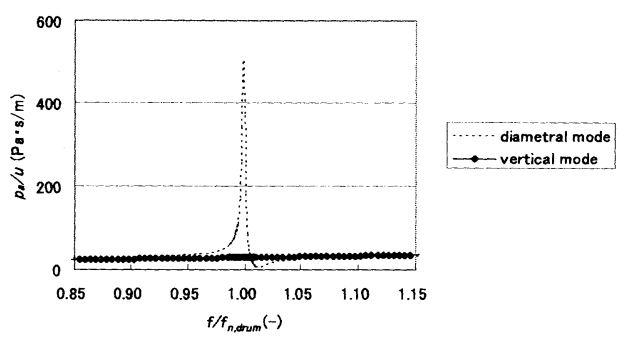

Fig.10 Impedance at the drum inlet nozzle. Integrated model is applied.

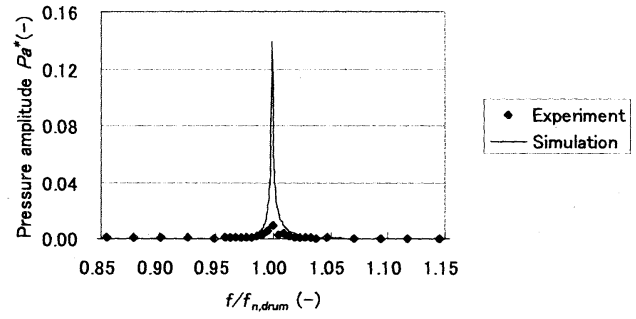

Fig.11 The frequency response of pressure pulsations in the drum around the resonant frequency in the drum. Separated model is applied.

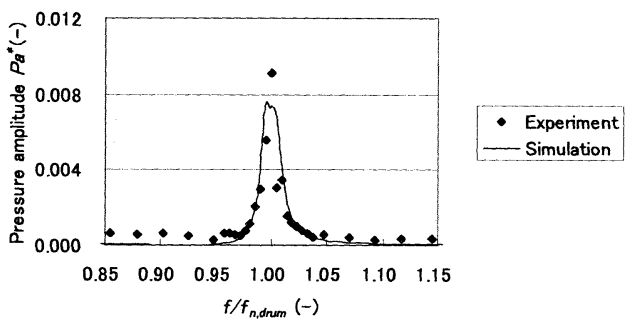

Fig.12 The frequency response of pressure pulsations in the drum around the resonant frequency in the drum. Integrated model is applied.

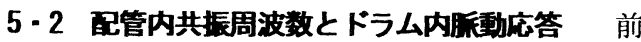
述 $5 \cdot 1$ 項に示したとおり，等価抵抗係数を適用した配 管・ドラムの一体型モデルによって，配管内の共振周 波数とドラム内の共振周波数が一致した条件でもドラ ム内脈動応答が良好に評価できることが示された。 し たがって，以降では一体型モデルにより，配管内の共 振周波数がドラム内の脈動応答に与える影響に関する 検討を行った. 図 13 および図 14 に配管内共振周波数 を変化させたときの，吖出配管内およびドラム内脈動 の周波数応答を示す. 本検討では, 配管内共振周波数 を任意に変化させるため, 計算上配管内の音速を変化 させた. なお，図 13，図14 では各音速条件における配 管内 3 次モードとドラム内径方向モードの共振周波数 の比 $f_{n, p i p}$ *をパラメータとして示す. 図 13 より, 配管 内脈動忘答の最大值は, 配管内共振周波数が变化して もほぼ一定の值になることが分かる。一方，図14に示 すドラム内脈動応答に関しては, 配管内共振周波数と ドラム内共振周波数の比に応じて, 最大脈動応答が変 化することが明らかとなった。

次に，ドラム内最大胍動応答が変化する原因に関し て検討するため, 図 15 に示すように配管内共振周波数 とドラム内最大脈動応答の関係について検討する. 図 15 中 $y$ はドラム内線形減衰を表しており， $\gamma$ 
$=2.216[\mathrm{Ns} / \mathrm{kgm}]$ が実験により同定した線形减衰である.

ドラム内減衰に関しては次項で詳細を述べる. 図 15 ( $\gamma$ $=2.216)$ より，ドラム内最大脈動応答は，配管内共振 周波数とドラム内共振周波数が完全に一致したときで はなく，両者が数\%ずれたときに最も大きくなることが 明らかとなった. 本現象の原因に関して検討するため, 図 16 にドラム内卓越周波数と配管内共振周波数 $f_{n, p i p}{ }^{*}$ の関係を示す.図 16 より $f_{n \text { pip }}$ *が 1.0 に近づくにつれ, ドラム内最大脈動応答を与える周波数がドラム内共振 周波数からかい離することが分かる. $f_{n p i p}$ *が 1.0 にお いて卓越周波数が不連続に変化するのは図 9 に示すよ

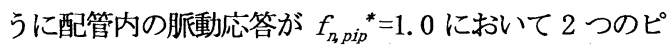
一クを有することに起因していると考えられる. 図 16 に示すようにドラム内の卓越周波数が $f_{n, p i p}$ 记応じて変 化するため, 図 $17(\gamma=2.216)$ に示すドラム内の応答 倍率（ドラム内圧力脈動振幅と, ドラムノズル部にお ける変動速度振幅の比）は $f_{n, p i p}$ *が 1.0 に近づくにつれ 小さくなる.一方, ドラムへの加振力となる配管内脈 動応答に関しては, 図 18 に示す通り, $f_{n, p i p}$ *が 1.0 に近 づくにつれて大きくなる. したがって，ドラム内脈動 応答は, 加振力と応答倍率の積によって求められるこ とから, 図 $15(y=2.216)$ に示すように, $f_{n, p i p}{ }^{*} 1.0$ 付 近で極小值が存在することになる.

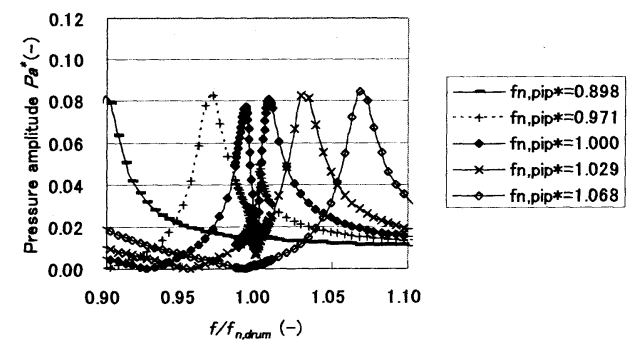

Fig.13 The frequency response of pressure pulsations in the discharge pipe. The resonant frequency in the pipe is changed.
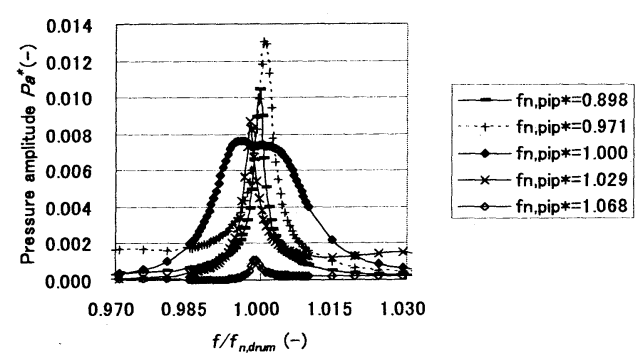

Fig.14 The frequency response of pressure pulsations in the drum. The resonant frequency in the pipe is changed.

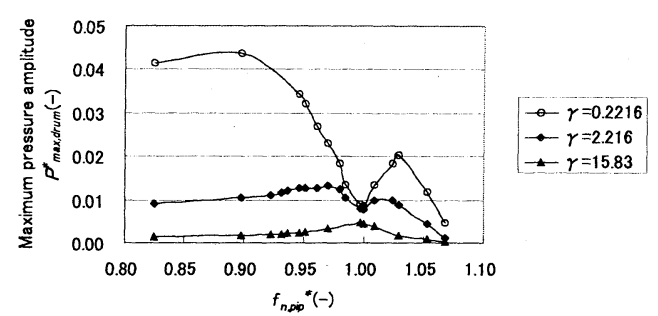

Fig.15 The relation between the maximum pressure amplitude in the drum and the resonant frequency in the pipe.

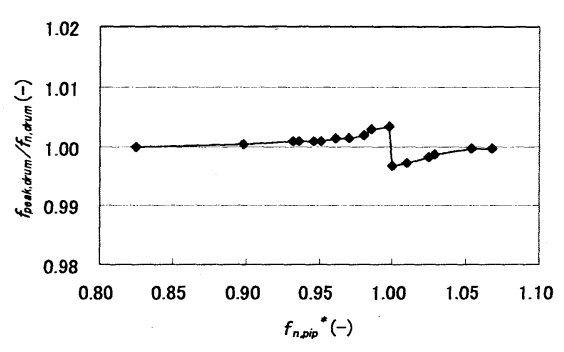

Fig.16 The relation between the peak frequency in the drum and the resonant frequency in the pipe. $\gamma=2.216[\mathrm{Ns} / \mathrm{kgm}]$.

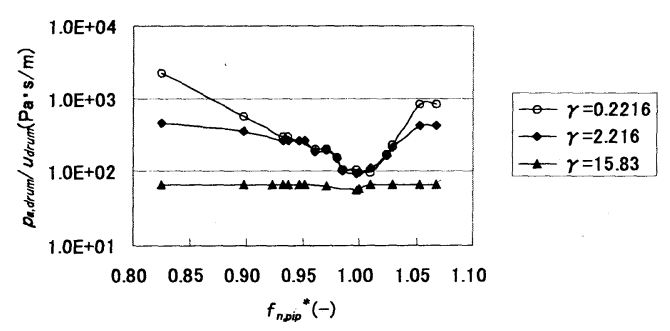

Fig. 17 The relation between the ratio of the pressure response to the velocity excitation and the resonant frequency in the pipe.

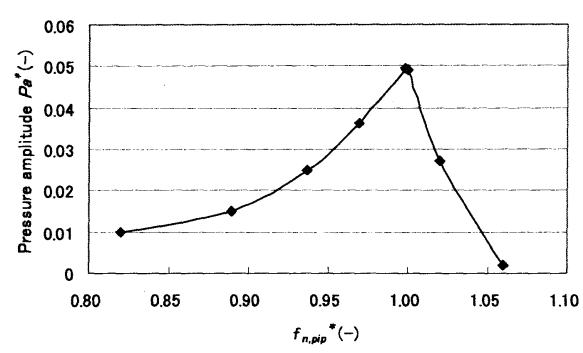

Fig.18 The relation between the pressure amplitude in the discharge pipe at the peak frequency in the drum and the resonant frequency in the pipe. $\gamma=2.216[\mathrm{Ns} / \mathrm{kgm}]$. 
5 - 3 ドラム内洼衰の影響 ドラム内の音響减衰 に関しては, 音響加振試験の結果から，式(6)を用いて 臨界減衰係数に対する減衰比を実験的に算出した，さ らに，その減衰比を用いて，モード重合法により求め た脈動応答とドラム内流体に均質な線形减衰を与えて 算出した脈動応答が等しくなるように等価な線形減衰 を求めた. 実験より算出したドラム内の减衰比は $0.07 \%$ であり，等価な線形減衰 $\gamma$ は $2.216[\mathrm{Ns} / \mathrm{kgm}]$ であった.

$$
p_{a}(t)=p_{a}(0) e^{-\xi \omega t}
$$

ドラム内流体の音響城衰は，流体の物性，温度，圧 力などのプロセス条件によって変化する．そこで，ド ラム内減衰がドラム内の脈動応答に与える影響に関し て検討するため，本実験条件で算出した減衰比の $1 / 10$ である減衰比 $0.007 \%(y=0.2216[\mathrm{Ns} / \mathrm{kgm}])$ ならびに減 衰比 0.5\%（ $(\gamma=15.83[\mathrm{Ns} / \mathrm{kgm}] ）$ に関して同样の計算を 行った. 図 15 にドラム内線形減衰を変化させて算出し た配管内共振周波数とドラム内最大脈動応答の関係を 示す. 図 $15(\gamma=0.2216)$ より, ドラム内の減衰が小さ くなると $f_{n, p i p}$ *が 1.0 に近づくにつれドラム内最大脈動 応答が小さくなる傾向がより顕著になることが明らか となった。一方，ドラム内堿衰が大きくなると（ $\gamma$ =15. 83），逆に $f_{n, p i p}$ *゙ 1.0 に近づくにつれドラム内最 大脈動応答が大きくなることが示された. このように

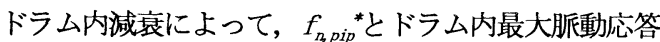
の関係が異なるのは, 図 17 に示すドラム内の応答倍率

(ドラム内圧力脈動振幅と，ドラムノズル部における 変動速度振幅の比）に関連している. 図 17 より,ドラ ム内堿衰が小さくなると $(\gamma=0.2216) f_{n, p i p}$ *が 1.0 に近 づくにつれ応答倍率が小さくなるが，ドラム内減衰が 大きい場合 $(\gamma=15.83)$ には $f_{n, p i p}$ そよらずほぼ一定の 応答倍率となるため, 配管内脈動応答の特性に応じて, ドラム内脈動応答も $f_{n p i p}{ }^{*} か ゙ 1.0$ で最大になることが明 らかとなった．したがって，配管から伝播される圧力 脈動によってドラム内で励起される最大脈動応答を算 出する際には，ドラム内減衰が大きい流体に関しては， 配管内共振周波数とドラム内共振周波数が一致した条 件を求めればよく，減衰が小さい流体の場合には両共 振周波数がずれた条件に関してもドラム内脈動応答を 求める必要があると言える.

5 -4 ドラム内音䅧モードの影響 配管内共 振周波数とドラム内共振周波数との関係がドラム 内脈動応答に与える影響に関しては，前述のとお り図 7 に示す径方向モードを対象として検討を行
った.しかしながら 3 次元ドラムの形状, 音速, 対象周波数が異なれば，ドラム内では径方向のみ ならず样々な形態の音響モードが存在することか ら，ドラム内音響モード形状が配管内およびドラ ム内脈動応答に与える影響を把握するため, 図 19 に示す縦方向の音響モードに関して，同様の検討 を行った。なお，図 19 ではドラム内の音速を変化 させることで, 図 7 同様 $206 \mathrm{~Hz}$ で縦方向のドラム 内音響モードを励起した。

図 20 にドラム内縦方向モード付近におけるドラ 厶内最大脈動応答と配管内共振周波数の関係を示 す. 図 20 より，ドラム内減衰によらず $f_{n, p i p}$ 肪 1.0 のときドラム内脈動応答が最も大きくなることが 明らかとなった。これは, 対象としたドラム内綎 方向モードでは，配管とドラムの接続部が圧力モ 一ドの節に位置していることに起因している。す なわち, 図 19 のモードでドラム内共振が発生して も配管・ドラム接続部の圧力振幅が小さく，ドラ 厶内脈動応答が配管内脈動応答に与える影響が小 さいため, 図 7 に示したドラム内径方向モードの ような音響動吸振効果が現れないと考えられる. このことは図 10 に示すドラム接続部のインピーダ ンスからも確認できる. 図 10 より，ドラム内で縦 方向モードが励起される場合には，共振周波数に おいてもインピーダンスが変化しないため，ドラ ム内の共振が配管内の脈動応答に影響を与えない ことがわかる。したがって，配管・ドラム接続部 がドラム内圧力分布の節に相当する場合には，配 管内共振周波数とドラム内共振周波数が一致した 条件に関して, ドラム内脈動応答を求めれば最大 值を評価することができる.

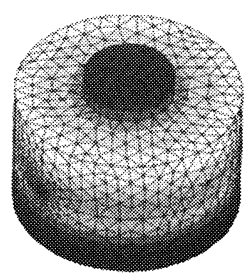

Fig.19 Pressure response of the vertical resonant mode in the drum at $206 \mathrm{~Hz}$ 


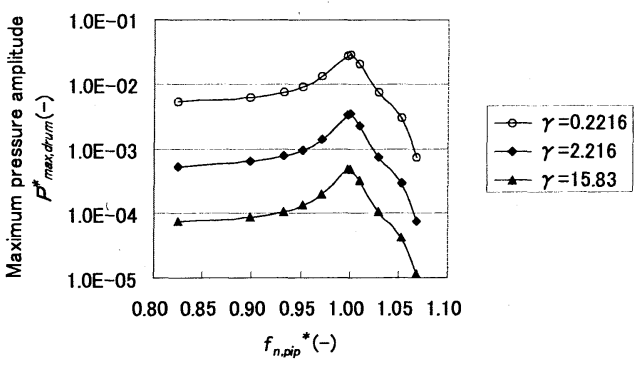

Fig.20 The relation between the maximum pressure amplitude in the drum and the resonant frequency in the pipe. Vertical resonant mode is excited in the drum.

\section{5 - 5 計算手法の此較 $5 \cdot 1$ 項で述べたよう}

に配管内脈動応答の最大值の算出においては, 配 管モデルからドラムを分離し, 配管・ドラム接続 部を開口端境界として扱えることが示された。一 方, ドラム内脈動応答に関しては, 配管内共振周 波数とドラム内共振周波数が一致した条件におい て, 分離型モデルと一体型モデルとで, 計算結果 が大きく異なることが示された，そこで，両計算

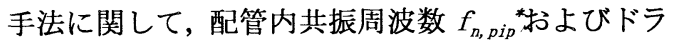
ム内音響モードが異なる条件で, ドラム内脈動応 答の比較検討を行った. 図 21 にドラム内径方向モ ード, 図 22 にドラム内縦方向モードが励起される 条件で, 配管内共振周波数を変化させたときに得 られるドラム内最大脈動応答の算出結果を示す. 図 21 より, ドラム内で径方向モードが励起される 場合には，分離型モデルを用いた計算では， $f_{n, p i p}{ }^{*}$ $=1.0$ においてドラム内脈動応答が最大となること から，ドラム内共振を考慮した一体型モデルを用 いた計算結果との差異が $f_{n, p i p}{ }^{*}=1.0$ において最も 大きくなることが明らかとなった. 一方, 図 22 よ り，ドラム内で図 19 に示すような縦方向モードが 励起され, 配管接続位置がドラム内圧力分布の節

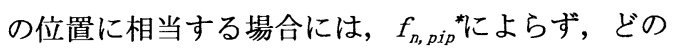
条件においても分離型モデルと一体型モデルの差 異は同程度となることが示された. 本比較検討結 果から, 配管系に接続されたドラム内の脈動応答 算出においては, ドラム内で励起されるモード形 状によらず, 分離型モデルを適用することで安全 側の評価が可能であることが明らかとなった。な お, 音響動吸振効果が小さい条件でも両計算手法 の結果が異なっているのは, 配管・ドラム接続部 における径方向速度分布の違いが影響していると 考えられる.

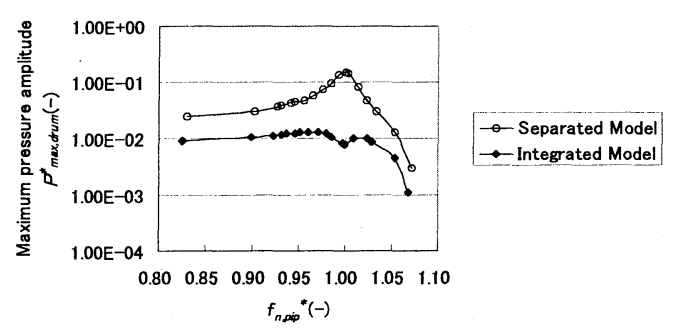

Fig.21 The relation between the maximum pressure amplitude in the drum and the resonant frequency in the pipe. Diametral resonant mode is excited in the drum with $\gamma=2.216[\mathrm{Ns} / \mathrm{kgm}]$.

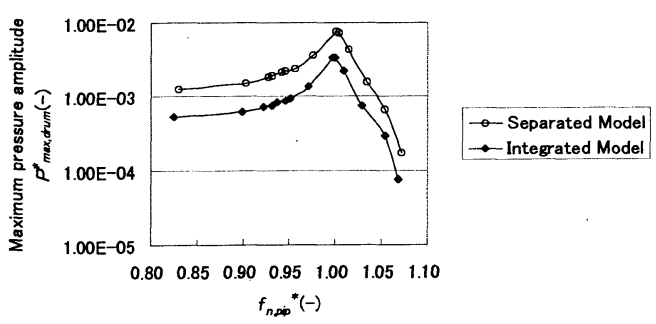

Fig.22 The relation between the maximum pressure amplitude in the drum and the resonant frequency in the pipe. Vertical resonant mode is excited in the drum with $\gamma=2.216[\mathrm{Ns} / \mathrm{kgm}]$.

\section{6. 耛 言}

ドラムを含む配管系に設置された遠心圧縮機か ら生じる圧力脈動に関して, ドラム内の 3 次元脈 動応答を評価するために, 1 次元で構築した配管内 圧力脈動の評価モデル ${ }^{(2)}{ }^{(3)}$ を 3 次元の音響要素モ デルに拡張した．本モデルでは配管系内で生じる 非線形減衰を等価抵抗係数としてモデル境界にお ける集中定数として扱うことにより，配管内の脈 動計算時には，配管内減衰を考慮せずに配管内お よびドラム内の 3 次元脈動応答が良好に評価でき ることを示した．また，ドラム内脈動応答の評価 手法に関して, 以下の知見を得た.

・本計算手法により，配管内共振周波数とドラム 内共振周波数が一致した条件で生じる音響動吸 振効果が良好に評価できる.

・ドラム内減衰, ドラム内音響モードの影響で, ドラム内共振時に配管・ドラム接続部の圧力振 
幅が大きくなる場合には，配管内共振周波数と ドラム内共振周波数が数\%ずれた条件でドラム 内脈動応答が最大となる.

・配管とドラムを分離した計算手法では，ドラム 内脈動忘答が実際より大きく算出されるため, 機器の防振の観点からは安全側の設計が可能と なる。

\section{文献}

(1) Ohta, Y., Outa, E., and Tajima, K., Characteristics of Blade Passing Frequency Noise of a Centrifugal Fan, and a Method for Noise Reduction, Transactions of the Japan Society of Mechanical Engineers, Series B, Vol. 54, No.500 (1987), pp. 890-899

(2) Hayashi, I., and Kaneko, S., Pressure Pulsations in Piping Systems Excited by a Centrifugal Compressor (1st Report, Evaluation Model and Characteristics of Pressure Pulsations under Resonant Conditions), Transactions of the Japan Society of Mechanical Engineers, Series C, Vol. 73, No.732 (2007), pp. 2255-2262.

(3) Hayashi, I., and Kaneko, S., Pressure Pulsations in Piping Systems Excited by a Centrifugal Compressor (2nd Report, Effect of Operating Conditions on Damping Characteristics), Transactions of the Japan Society of Mechanical Engineers, Series C, Vol. 74, No.739 (2008), pp. 650-657.

(4) Matsuda, M., Izuchi, H., Hayashi, I., Takeda, M., Maeda, S., "Pressure Pulsation Analyser", Japnese Patent Disclosure No. 2007-018040 (2007)

(5) Desmet, B., and Barrand, J. P., Proceedings of the 13th IAHR Symposium Montreal, No.18(1986), pp.1-14.

(6) Goto, M., Pressure Pulsation in a Centrifugal Pump-Piping System (1st Report, Experimental Examination of Characteristics for Pressure Pulsation), Transactions of the Japan Society of Mechanical Engineers, Series B, Vol. 54, No.502 (1987), pp. 1364-1370.

(7) Goto, M., Pressure Pulsation in a Centrifugal Pump-Piping System (2nd Report, Pressure Distribution in a Pipe and Effects of Pump Configuration on Pressure Pulsation), Transactions of the Japan Society of Mechanical Engineers, Series B, Vol. 54, No.502 (1987), pp. 1371-1377.

(8) Hayashi,I., and Guo,S., Acoustically Induced Vibration of Drums Excited by Rotating Machinery, ASME, PVP2005 Vol.4, No71380 (2005), pp.525-534.
(9) Tanaka, K., and Mori, M., Study on Pressure Pulsation of Reactor Pressure Vessel and PLR-Piping Systems, Proceedings of the Dynamics and Design Conference 2007, the Japan Society of Mechanical Engineers, No.07-8, 818 (2007) 